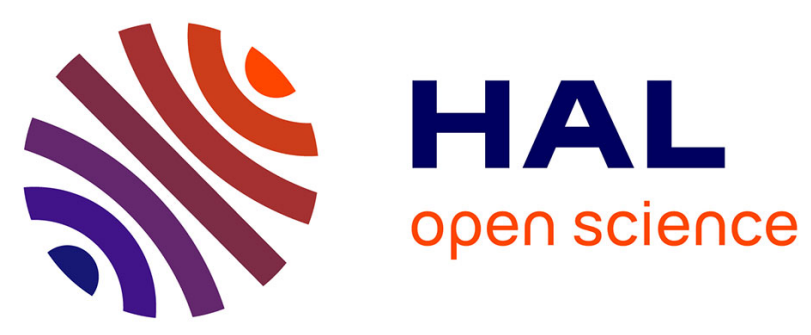

\title{
Enhanced Bio-inspired Microsensor Based On Microfluidic / Bacteria / Love Wave Hybrid Structure For Continuous Control Of Heavy Metals Toxicity In Liquid Medium
}

Ibtissem Gammoudi, Vincent Raimbault, Hakim Tarbague, Fabien Moroté, Christine Grauby-Heywang, Ali Othmane, Rafik Kalfat, Daniel Moynet, Dominique Rebière, Corinne Dejous, et al.

\section{- To cite this version:}

Ibtissem Gammoudi, Vincent Raimbault, Hakim Tarbague, Fabien Moroté, Christine GraubyHeywang, et al.. Enhanced Bio-inspired Microsensor Based On Microfluidic / Bacteria / Love Wave Hybrid Structure For Continuous Control Of Heavy Metals Toxicity In Liquid Medium. Sensors and Actuators B: Chemical, 2014, 198, pp.278-284. 10.1016/j.snb.2014.01.104 . hal-00937963

\section{HAL Id: hal-00937963 https://hal.science/hal-00937963}

Submitted on 25 Feb 2015

HAL is a multi-disciplinary open access archive for the deposit and dissemination of scientific research documents, whether they are published or not. The documents may come from teaching and research institutions in France or abroad, or from public or private research centers.
L'archive ouverte pluridisciplinaire HAL, est destinée au dépôt et à la diffusion de documents scientifiques de niveau recherche, publiés ou non, émanant des établissements d'enseignement et de recherche français ou étrangers, des laboratoires publics ou privés.

\section{()ㅜ) $\Theta$}

Distributed under a Creative Commons Attribution - NoDerivatives| 4.0 International 


\title{
Enhanced bio-inspired microsensor based on microfluidic/bacteria/love wave hybrid structure for continuous control of heavy metals toxicity in liquid medium
}

\author{
I. Gammoudi a,b,c,d,*, V. Raimbault ${ }^{\mathrm{a}}$, H. Tarbague ${ }^{\mathrm{a}}$, F. Moroté ${ }^{\mathrm{b}}$, C. Grauby-Heywang $^{\mathrm{a}, \mathrm{b}}$, \\ A. Othmane ${ }^{c}$, R. Kalfat ${ }^{d}$, D. Moynet ${ }^{e}$, D. Rebière ${ }^{a}$, C. Dejous ${ }^{a}$, T. Cohen-Bouhacina ${ }^{b}$ \\ a Univ. Bordeaux, IMS, CNRS UMR 5218, IPB, Univ. Bordeaux 1, 351 crs Libération, 33405 Talence, France \\ b Univ. Bordeaux, LOMA, CNRS UMR 5798, 351 crs Libération, 33405 Talence, France \\ c Biophysics Laboratory, Faculty of Medecine, Monastir 5019, Tunisia \\ ${ }^{\mathrm{d}}$ National Institute for Research and Physicochemical Analysis, BiotechPole, Sidi Thabet, Tunisia \\ e Univ. Bordeaux, Laboratory of Immunology, Bordeaux 33706, France
}

Keywords:

Bacteria-biosensor

Love wave

Microfluidics

AFM

Heavy metals

Layer by layer

\begin{abstract}
A B S T R A C T
Environmental pollution by toxic heavy metals (HM) presents a real threat for aquatic medium and human health. Therefore aquatic ecosystem management requires early warning systems for on line monitoring. Microtechnologies can give rise to innovative bio-inspired hybrid microsensors, likely to meet this need and providing cost reductions by reducing reagents consumption and manufacturing cost.

This work deals with a bacteria-based Love wave sensor, with enhanced properties provided by integration of a polydimethylsiloxane (PDMS) microfluidic network for a better control of the sample flow, and devoted to in situ monitoring of $\mathrm{Cd}(\mathrm{II})$ and $\mathrm{Hg}(\mathrm{II})$. Whole Escherichia coli (E. coli) bacteria are used as bioreceptor, mimicking in vivo enzymatic activity. They were immobilized on polyelectrolyte multilayer (PEM) films realized using layer by layer technique (LbL) with alternatively adsorption of positive and negative chains. The acoustic delay line was inserted into an electronic oscillation loop for real time monitoring.

Compared to previous work, this paper deepens the results obtained with two types of microfluidic chips (measurements in static and dynamic modes), including analysis in terms of reproducibility. These results are analyzed and interpreted thoroughly leading to assumptions about the phenomena involved in the detection mechanisms. These hypotheses are validated through a pioneering study with atomic force microscopy (AFM), performed to characterize bacteria adhesion and to establish the relationship between bacteria morphological evolution and mechanical properties. AFM was chosen for its ability to maintain the bacteria alive during the experience without inducing irreversible damage.

The resulting microsystem led to efficient HM detection, characterized by a reduced response-time (less than $60 \mathrm{~s}$ ) and a detection limit inferior to $10^{-12} \mathrm{M}$. AFM measurements have demonstrated a high bacterial attachment and the stressing effect of toxic HM on bacterial morphological state. These results are consistent with those obtained from Love wave measurements.
\end{abstract}

\section{Introduction}

Heavy metal (HM) pollution is posing significant threats to the environment and serious public health problems because of its toxicity (Bertin et al., 2006, [1]), non-biodegradability and bioaccumulation [2,3]. Indeed, HM may enter the human body through food, water, air or by skin absorption, and they become toxic when

\footnotetext{
* Corresponding author at: Univ. Bordeaux, IMS, CNRS UMR 5218, IPB, Univ. Bordeaux 1, 351 crs Libération, 33405 Talence, France.

E-mail address: ibtisem.gammoudi@u-bordeaux1.fr (I. Gammoudi).
}

they are not metabolized by the body and accumulate in the soft tissues. Therefore, it is important to be aware of risks, to be able to track HM and to understand how they act in order to take protective measures against excessive exposure.

Many techniques as X-ray fluorescence [4], atomic emission [5] or absorption spectrometry [6] or chromatography [7] are employed for metal detection but these methods are poorly suited to in situ analysis.

Sensor is seen as a benefit compared to other means which are heavy and cumbersome. In recent years, biosensor has become an integral part of all technological advances [8,9]. Several sensors have been developed for toxic compounds detection including 
(a)

(b)

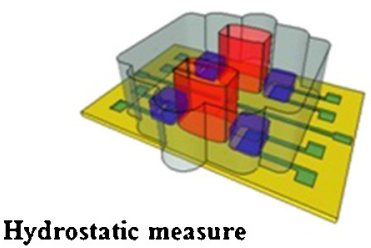

(c)

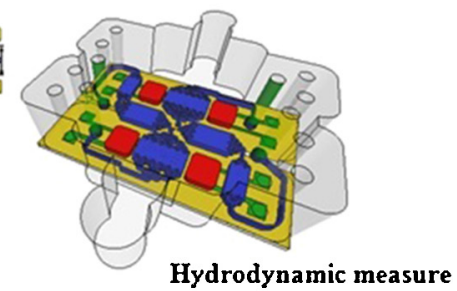

Fig. 1. (a) Schematic view of a dual surface acoustic Love wave (b) hydrostatic PDMS cell (c) microfluidic PDMS cell.

Cadmium HM $[10,11]$. The aim of this study is to develop portable and disposable sensors. The use of bacteria as a bioreceptor mimicking in vivo enzymatic activity, can allows us to move from a multi-enzyme to a cellular bioreceptor, from in vitro to in vivo biochemical recognition. It is also a good way to study effects of HM on microorganisms, as HM generally exert an inhibitory action on microorganisms by blocking essential functional groups, displacing essential metal ions, or modifying the active conformations of biological molecules [12,13]. Exposure to HM ions can also lead to cellular disfunctioning like DNA damage [14], enzyme alteration and cell membrane disruption [15].

Biochemistry analysis systems used with microelectronic techniques are widely used in biosensor's field. Therefore the study of microfluidic sensor has become an important aspect of the analytical instrumentation. One of the polymers commonly used in developing micro-biosensor operating in liquid medium is poly-dimethylsiloxane (PDMS) [16-18], due to its versatile and favorable properties, which include non-toxicity, biocompatibility, flexibility, low cost, and easy fabrication [19]. Microfluidic devices obtained by photolithography and molding are now widely used because of their numerous advantages such as sample holding, reagent mixing, separation and detection $[20,21]$.

In this paper, we present a hybrid structure combining PDMS microfluidic chip for flow control and bacteria-based Love wave transducer, devoted to in situ monitoring of HM for environmental control applications. Materials and methods involved in the device are presented in Section 2. Then, results obtained during PEM and bacteria deposition, as well as during detection of Mercury and Cadmium, are exposed and analyzed. They are compared to previous results obtained with PDMS cell for static measurements [22], bringing to light enhanced response time and sensitivity allowed by dynamical measurements with microfluidic pattern. Monitoring of bacterial stress with AFM is also used for a better understanding of mechanisms involved in the interaction between bacteria and HM.

\section{Materials and methods}

\subsection{Love wave sensor}

The surface acoustic wave component has been chosen for its numerous advantages, specially high sensitivity, real-time working, robustness and versatility due to mechanical transducing effect. Details on the device can be found in ref. [23]. Briefly, it consists of a dual delay line deposited on an AT cut quartz substrate (Euler angles: $0^{\circ}, 121.5^{\circ}$, and $90^{\circ}$ ) used as the piezoelectric material. For each delay line, both Interdigital Transducers (IDTs) used for piezoelectric emission and reception of acoustic wave are made by sputtering $70 \mathrm{~nm}$ of gold on a $30 \mathrm{~nm}$ titanium layer to achieve a good are made by sputtering $70 \mathrm{~nm}$ of gold on a $30 \mathrm{~nm}$ titanium layer to achieve a good surface adhesion. IDTs are composed of $44 \mathrm{Ti} / \mathrm{Au}$ splitted-finger pairs with a periodicity $(\lambda)$ of $40 \mu \mathrm{m}$. The acoustic path length is $164 \lambda$ (between both IDTs), and the IDTs aperture $(W)$ is $39 \lambda$ [24]. A $4 \mu \mathrm{m}$ plasma enhanced chemical vapor deposited (PECVD) $\mathrm{SiO}_{2}$ layer is used as the guiding layer. Finally, the $\mathrm{SiO}_{2}$ was etched upon electrical contacts. These characteristics lead to a guided shear horizontal surface acoustic wave (guided SH-SAW), also called Love wave, with synchronous frequency $f_{0}$. This synchronous frequency is real time monitored with oscillating electronics [21] and represents the output signal of the sensor. It decreases typically upon added surfacic mass, and is also sensitive to other mechanical effects such as viscoelastic modifications [25].

\subsection{PDMS chips}

PDMS chips have been developed within previous works [26], in order to confine and control the fluid samples on the sensor surface. PDMS is a biocompatible material with interesting properties such as optical transparency, fast prototyping and good sealing properties on glass. The PDMS cell for static and dynamic measurements are schematically represented on Fig. 1b and can be briefly described. Both have chambers localizing fluids samples on the sensitive acoustic path between IDTs and air cavities upon IDTs to avoid capacitive coupling with conductive liquids. Both types of PDMS chips were pressed on the Love-wave component, instead of glued on it, in order to preserve easy surface accessibility. In the static configuration, fabrication process can be found in ref. [26], fluid samples were introduced with a micropipette in the open chambers. In the dynamic configuration micro channels were realized using standard soft photolithography methods [27] by means of silicon wafer with spin-coating of a SU-8 resin at $2000 \mathrm{rpm}$ to obtain a negative mold with $200 \mu \mathrm{m}$ membranes as polymer template, together with micromachining for external 3D shapes. The PDMS chip was then formed from a liquid PDMS oligomer and a cross-linking agent (weight ratio of 9:1). Both components were mixed and put with a syringe pump at flow equal to $1 \mathrm{ml} / \mathrm{min}$ to obtain a good homogenization of PDMS in the mold. After that, PDMS was cured for $20 \mathrm{~min}$ at $95^{\circ} \mathrm{C}$ and the resulting chip with the microfluidic network pattern was peeled of from the mold. Using a home-made test cell maintaining the PDMS chip with proper alignment and sealing on the Love wave device, the fluid sample 
was pulled through the acoustic path with programmable syringe pumps.

\subsection{Chemical and biological materials}

The sensitive biofilm of bacteria has been immobilized onto the surface of the Love wave platform through Polyelectrolytes (PE) multilayers. Polyelectrolytes used in our studies are a polycation, poly(allylamine hydrochloride $)(\mathrm{PAH})(\mathrm{MW}=56 \mathrm{kDa})$, and a polyanion, poly (styrene sulfonate) (PSS) (MW $=70 \mathrm{kDa}$ ), both purchased from Sigma-Aldrich. Adsorption of PE was done from TBS (Tris Buffered saline) solutions of constant ionic strength $(0.15 \mathrm{M})$ with a concentration of PE at $0.5 \mathrm{~g} / \mathrm{l}$.

PE were deposited through the "layer-by-layer" (LbL) method [28] resulting in self-assembled molecular multilayers PAH$(\mathrm{PSS}-\mathrm{PAH})_{n}$. Typically, PAH and PSS solutions were alternatively deposited, adsorption and rinsing steps were then repeated to obtain a desired numbers of PE layers. In this work the PAH-PSS bi-layers ended with a PAH layer (positively charged) were used to immobilize E. coli (negatively charged). This bacterium is used as bioreceptor because of its sensitivity to HM, as presented in the introduction part. E. coli, acquired from the Centre d'Etudes du Bouchet (DGA, France), were grown overnight in Petri dishes containing LB solid agar nutritive medium. They were suspended in $0.15 \mathrm{M}$ TBS (buffer) to obtain a final D.O. (optical density at $600 \mathrm{~nm}$ ) equal to 0.6 corresponding to concentration of $10^{8}$ cells $/ \mathrm{ml}$, that allowed good coverage of the biofilm on the sensor surface (results not shown).

The reference solutions of cadmium and mercury were prepared from $\mathrm{Cd}\left(\mathrm{NO}_{3}\right)_{2} \cdot\left(\mathrm{H}_{2} \mathrm{O}\right)_{4}$ and $\mathrm{Hg}\left(\mathrm{NO}_{3}\right)_{2} \cdot\left(\mathrm{H}_{2} \mathrm{O}\right)$ (from Sigma-Aldrich) in the same TBS buffer $(0.15 \mathrm{M})$. The platform was subjected to four selected concentrations of each metal: $10^{-12} \mathrm{M}, 10^{-9} \mathrm{M}, 10^{-6} \mathrm{M}$ and $10^{-3} \mathrm{M}$. These concentrations were chosen as representative to study the sensitivity and reproducibility of the device over a large range and to evaluate the interest of such a sensor for environmental applications.

\subsection{Atomic force microscopy}

AFM was used to probe bacteria morphology and behavior in a physiological environment and in real time. In this work, the effect of the $\mathrm{Cd}^{2+}$ concentration on the bacterial cell surface behavior was examined.

AFM experiments were carried out with a Bioscope II mounted on an Olympus inverted optical microscope and operating with the NanoScope V controller (Veeco-Brucker, Santa Barbara, CA). This technique is based on the detection of small forces existing between a tip and an object (the surface sample) which is scanned along the tip with a piezo scanner (maximum XYZ scan range of $150 \mu \mathrm{m} \times 150 \mu \mathrm{m} \times 12 \mu \mathrm{m}$ ). The tip is attached on one end of a cantilever which is "built in" at the other end. This technique can generate information such as topography and mechanical properties at the nanometer level. Indeed, images obtained with AFM provide not only information about the (2D and 3D) topography of the studied sample (bacteria morphology) but also its mechanical properties such as adhesion, elasticity, viscoelasticity or chemical composition with friction and/or phase images [29-33]). In the present work, experiments were achieved in liquid and with the AFM contact mode. So, first, the biosensor surface is scanned in the three directions of space (imaging mode), this allows, for example, to provide information such as bacteria density on the biosensor surface, bacteria morphology (shape and size), etc. Then, and in order to access to the bacteria mechanical properties, force curves (FC) are obtained and collected from measuring the cantilever deflection as the sample was moved toward the tip in the $z$ direction (spectroscopic mode).
All data presented in this paper were generated with the same cantilever (the spring constant of the cantilever used was nominally of about $0.58 \mathrm{~N} / \mathrm{m}$ ) and an imaging scan rate at $0.5 \mathrm{~Hz}$. For each experiment, four images were recorded at the same time: trace and retrace height images, trace deflection image (signal error) and friction images (mechanical properties) [35]. For more clarity, images are flattened and only the trace height ones are shown in this paper.

\section{Results and discussion}

\subsection{Acoustic responses during polyelectrolytes multilayers and bacteria deposition}

The real-time characterization of PE multilayer coating is based on the modification of the acoustic wave phase velocity and so the oscillator frequency, due to mass loading of the surface.

Also, the frequency variation in real time has allowed us to optimize the flow rate. Indeed, we have selected each time a flow rate involving an improved frequency variation within the shortest time.

We will discuss in the following the results obtained for different stages of development and realization of biosensor.

The steps of the Fig. 1a (top curve) show a fast decrease in real-time signal during the injection in micro-flow of both PE alternatively, followed by signal stabilization that needs only a few minutes after each PE indicating the end of the adsorption step. Optimal throughput was set at $20 \mu \mathrm{l} / \mathrm{min}$. It is observed that for each one of the three bilayers, the steady-state frequency change increases with each new injection (Fig. 1a, bottom). This curve also highlights the good reproducibility of these results. It has been shown that a cleaning step was needed at the end of each layer, unlike when using a PDMS chip for static measurements, for which rinsing steps seemed to be unnecessary, as similar frequency shifts were obtained, compared to same protocol with rinsing steps [22].

Bacteria immobilization was then monitored in real-time. An optimal flow rate was found to $15 \mu \mathrm{l} / \mathrm{min}$. It was observed a decrease of electronic signal, followed by signal stabilization after 20 min. A frequency variation 3-5 times greater than the variation found for the immobilization of bacteria in static mode [22] was obtained.

In parallel, a study was performed by AFM to optimize the protocol for the polyelectrolytes deposition in order to ensure full substrate coverage with homogeneous film and reduced number of aggregates.

\subsection{Acoustic responses during mercury and cadmium detection}

The real-time responses to different concentrations of $\mathrm{Cd}^{2+}$ and $\mathrm{Hg}^{2+}$ were studied (Fig. 2). Optimal throughput was set at $15 \mu \mathrm{l} / \mathrm{min}$ for heavy metals. Note an increasing frequency in the presence of heavy metals by increasing the levels and up to $10^{-3} \mathrm{moll}^{-1}$, with a detection threshold better than to $10^{-12} \mathrm{moll}^{-1}$. Beyond $10^{-3} \mathrm{moll}^{-1}$, a significant decrease in the frequency of several kilohertz can be observed. It was attributed to physico-chemical interactions, as similar effect is observed with a control line with $\mathrm{PE}$ and without bacteria (results not shown). This effect can partly explain the degradation of reproducibility appearing at high concentrations $\left(10^{-3} \mathrm{M}\right)$.

More generally, these phenomena can be attributed to changes in the viscoelastic properties, related to changes in the bacterial metabolism. Indeed, HM interact with the constituents of the membrane and inhibit some enzymatic activities of bacterium inducing a decrease in its viability. Qualitatively similar effects were observed previously, when compared with the static configuration where the solutions were injected with micropipette 
(a)

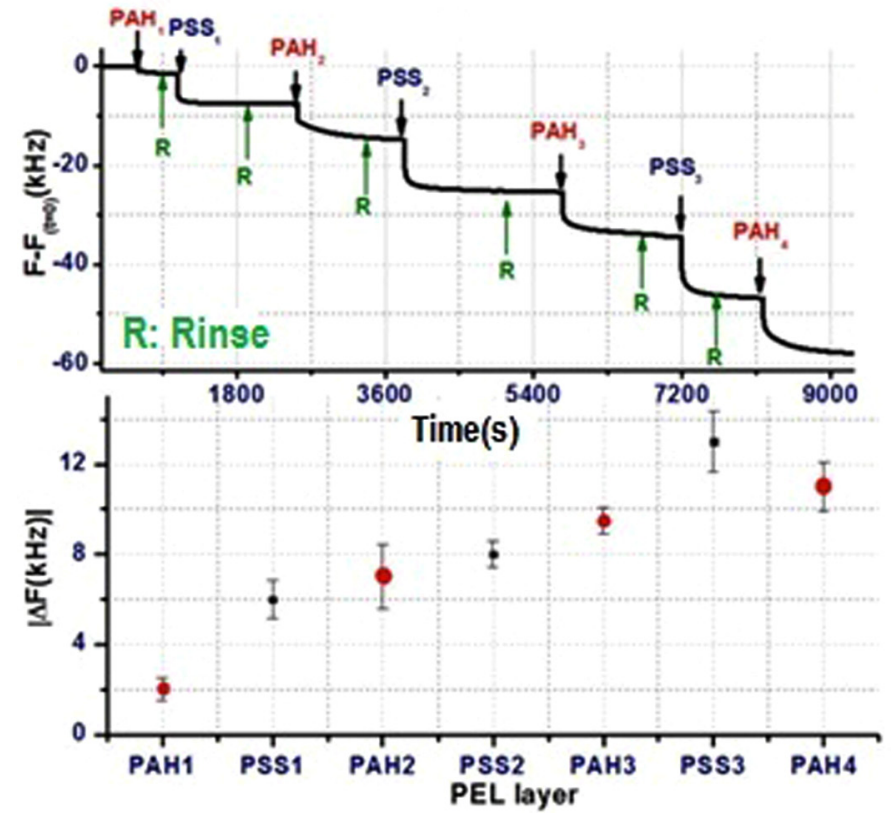

(b)

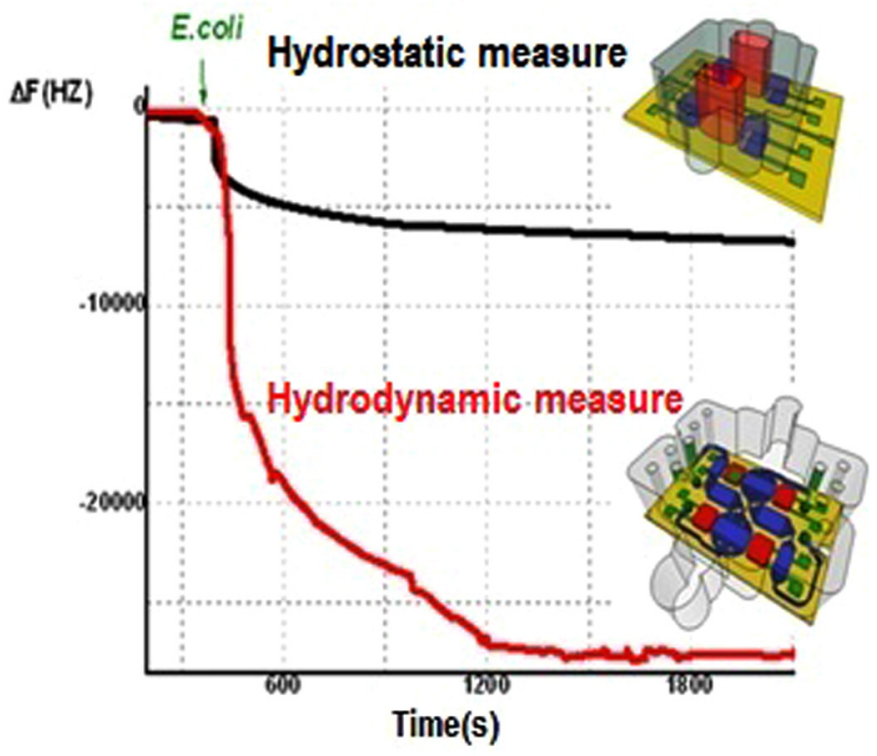

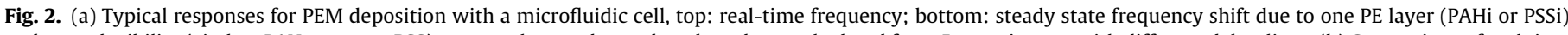

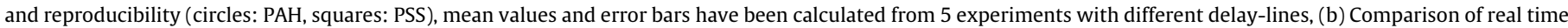
frequency responses to bacteria immobilization for static (top) and hydrodynamic (bottom) protocols.

[22]. It should be noted that characteristics have been improved with microfluidic system: the response time has been significantly reduced with effective detection within $60 \mathrm{~s}$, and the sensitivity has been enhanced (Fig. 2c), with detection limit still inferior to $10^{-12} \mathrm{M}$. These results demonstrate the importance of conducting tests under dynamic conditions. Also, the rate of injection of liquid and route to the sensitive surface of the sensor, as well as the flows form, significantly affect the interaction effectiveness between bacteria and the sensitive layer, as well as the effect mechanically induced on the transducing platform and therefore the response time and overall sensitivity. Thereby, with smaller analysis chambers $(100-300 \mu \mathrm{m}$ in height), and a better distri-
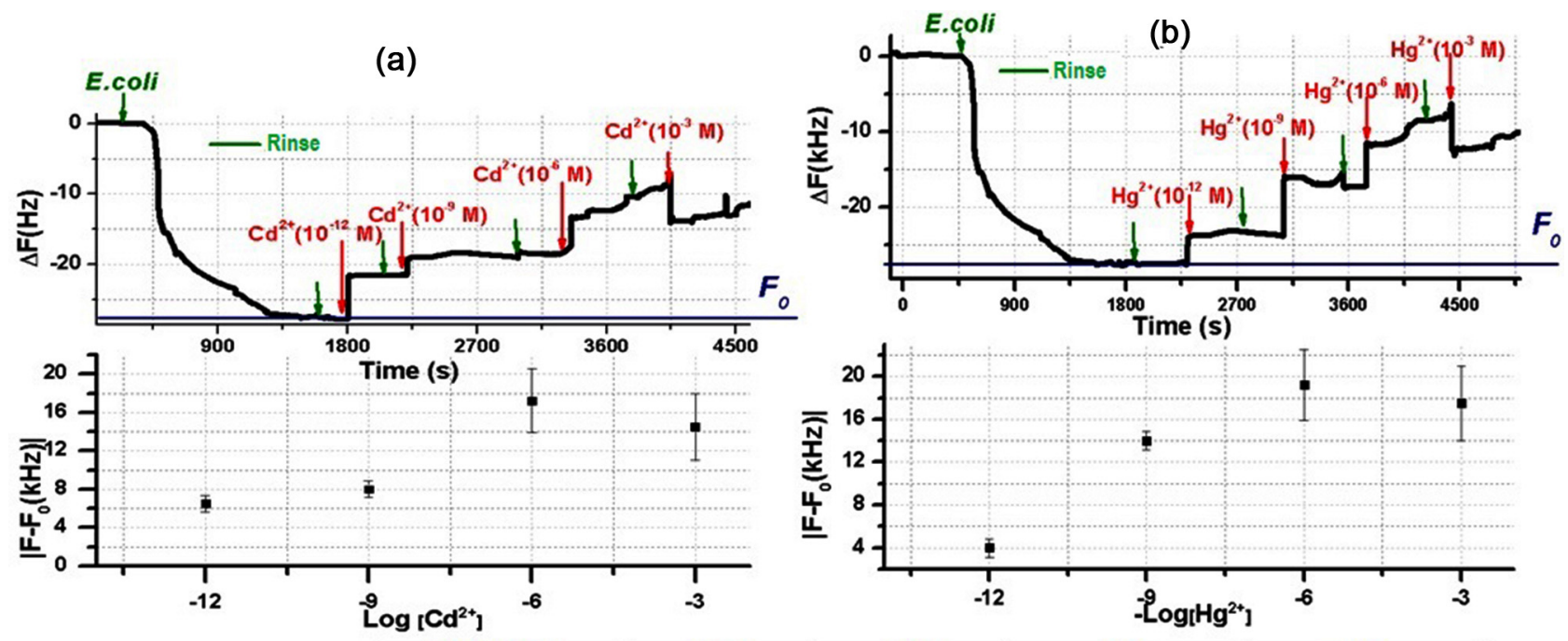

\begin{tabular}{|c|c|c|c|c|c|}
\hline \multirow{2}{*}{ (c) } & {$\left[\mathbf{M}^{2+}\right](\mathbf{M})$} & \multirow[t]{2}{*}{$10^{-12}$} & \multirow[t]{2}{*}{$10^{-9}$} & \multirow[t]{2}{*}{$10^{-6}$} & \multirow[t]{2}{*}{$10^{-3}$} \\
\hline & Heavy metals & & & & \\
\hline \multirow{2}{*}{$\begin{array}{c}\text { Static } \\
\text { measurement }\end{array}$} & $\mathrm{Cd}^{2+}$ & $3 \pm 0.52$ & $3.5 \pm 0.51$ & $5 \pm 1.15$ & $6 \pm 1.42$ \\
\hline & $\mathbf{H g}^{2+}$ & $2.5 \pm 0.5$ & $4.5 \pm 1$ & $7 \pm 1.32$ & $7.5 \pm 0.86$ \\
\hline \multirow{2}{*}{$\begin{array}{c}\text { Dynamic } \\
\text { measurement }\end{array}$} & $\mathrm{Cd}^{2+}$ & $6.5 \pm 0.84$ & $8 \pm 0.88$ & $17 \pm 3.30$ & $14 \pm 3.50$ \\
\hline & $\mathbf{H g}^{2+}$ & $4 \pm 0.85$ & $14 \pm 0.86$ & $19 \pm 3.32$ & $17 \pm 3.51$ \\
\hline
\end{tabular}

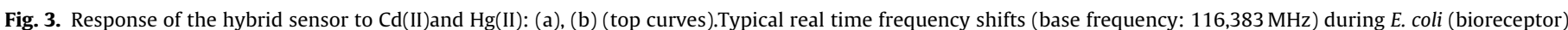

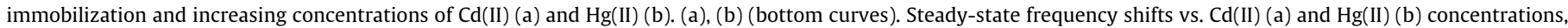

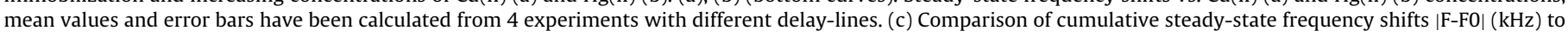
heavy metals detection with static and hydrodynamic protocols. 
(a)
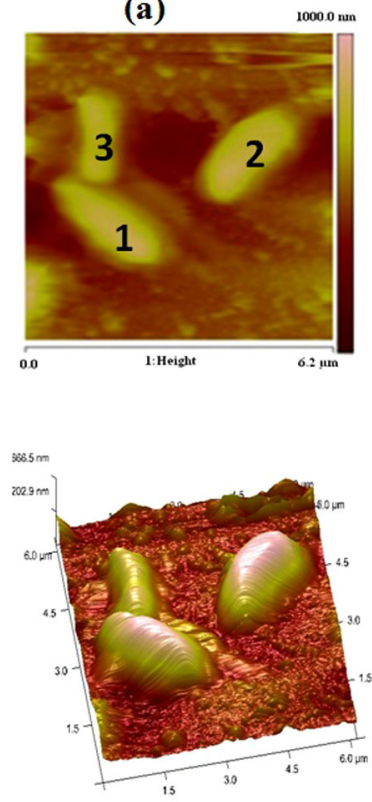

(b)
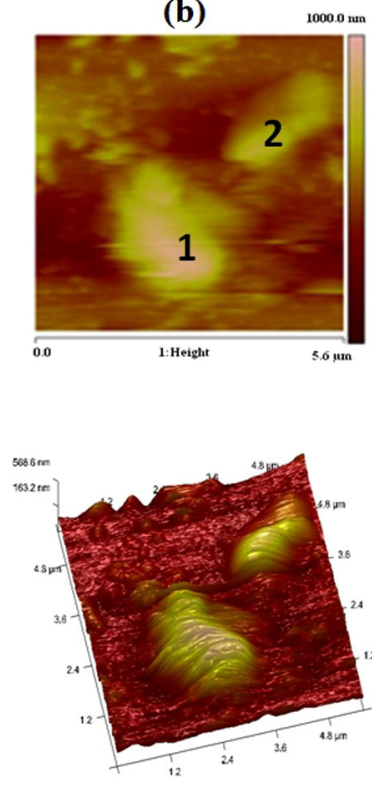

(c)

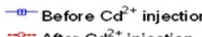

(d)

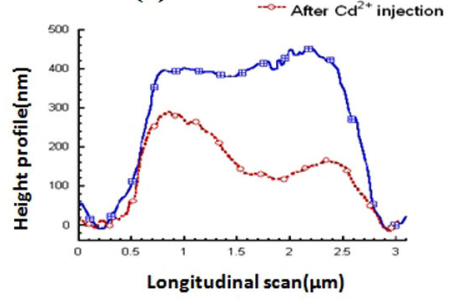

(e)

-- PEM substrate Q-- Before injection of $\mathrm{Cd}^{2+}$ -.-- After injection of $\mathrm{Cd}^{2+}$
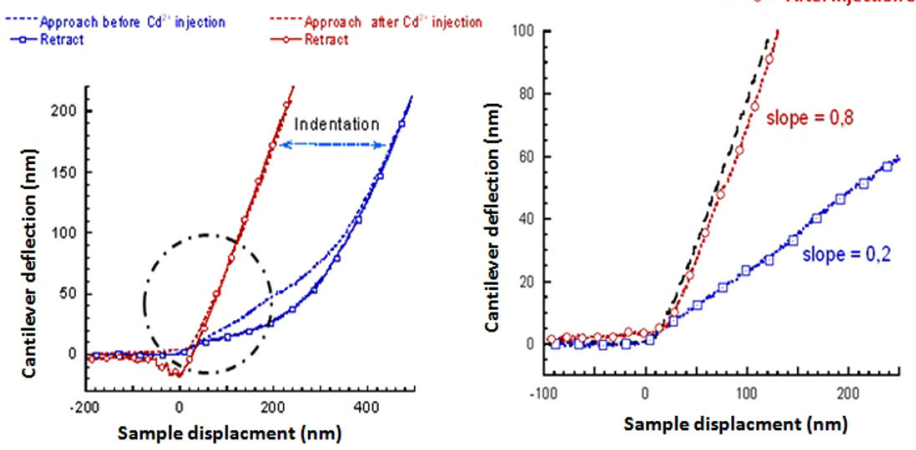

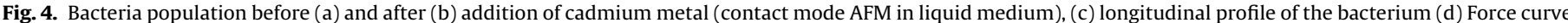
due to the elastic behavior of the bacteria before and after addition and (e) Force curve Zoom, longitudinal profile of the bacterium.

bution of liquid, the response time and in some cases the sensor sensitivity, can be improved.

The reproducibility was also verified and some results are reported on Fig. 1a (bottom) and Fig. 2a (bottom). As for PE and bacteria, responses to low concentration of HM show a good reproducibility. The degradation appeared at $10^{-6} \mathrm{M}$ and $10^{-3} \mathrm{M}$.

\subsection{Monitoring of bacterial stress by AFM}

Thorough investigation of bacteria morphology and mechanical properties evolution as function of heavy metal concentration was made with AFM measurements. Among results, it appeared that $\mathrm{HM}\left(\mathrm{Cd}^{2+}\right)$ had a definite effect on the behavior of the bacterial population immobilized on the biosensor.

Fig. 3a shows typically rod-shaped cells with smooth surfaces well attached on substrate. The addition of $\mathrm{Cd}^{2+}$ induced considerable damages resulting from changes on bacterial morphology (Fig. 3b) and on its adhesive properties. Indeed, a detachment of bacteria of the substrate can be observed (bacteria 3) following scanning tip while other bacteria remained attached (Number 1 and 2) but one can observe that their contours became less well defined which suggests a modification of the bacteria integrity. Besides, the AFM tip motion destabilized bacteria because it was sensitive to the external strain. This is result of hydrodynamic forces large enough to remove the cell (probably become less stable and less adherent), involving its displacement and then its detachment from substrate after a few scans (results not shown).

In order to complete this AFM study, we carried out nanoindentation comparative experiments on bacteria before and after injection of heavy metals (Fig. 3c). The obtained force curves are consistent with topographic results. Firstly, unlike the results obtained before injection of heavy metals, cells responses in presence of $\mathrm{Cd}^{2+}$ are not reproducible. In fact, approach-retract curves differ from one cell to another and from one area of the cell to another, indicating important variability in cell stiffness linked to variable states of degraded cells. Second, and from a qualitative point of view, superposition of approach curves obtained with bacteria after addition of $\mathrm{Cd}^{2+}$ to those of the substrate (PE layers) indicates the loss of cell elasticity behavior which can be correlated with degradation of bacteria. Also by analyzing the retract curve in the presence of cadmium, one notices the presence of several negative cantilever deflections while withdrawing the probe from the bacteria surface indicating tip contamination with the bacterial degraded cell content. In order to make a quantitative study, it would be interesting to follow the cell elastic behavior $[29,33]$ when varying gradually the cadmium concentration. We plan to carry out this study in the very near future.

Fig. 4.

\section{Conclusion}

A bacterial based Love wave microsensor was presented. Associated to new hydrodynamical PDMS chips integrating microfluidic network, this platform has lead to fast heavy metals detection, with efficient detection in less than $60 \mathrm{~s}$ with enhanced sensitivity and a detection limit better than $10^{-12} \mathrm{M}$ compared to the work of Stobiecka et al. [34] with a limit of detection LOD of 19 nM. AFM has emerged as a good complementary technique in this study. We observed real-time cell degradation following heavy metals injection through AFM images and force measurements on $E$. coli bacteria confirming the assumptions made on the basis of the results obtained with Love waves. This overall work put to evidence the interesting of this hybrid approach mixing electronics and micro-organisms for efficient detection of heavy metals, specially at very low concentration $\left(<10^{-6} \mathrm{M}\right)$.

\section{Acknowledgments}

This work on the bacterial-based hybrid biosensor for heavy metals detection was financially supported by the CMCU, project No. 10G1103. PDMS chips were designed in the frame of ANR project (Agence Nationale de la Recherche, PRECODD-BIOALERT program, and project ANR-06-ECOT-004). The authors thank M. Benoît (Réseau Technologique de Base, LAAS-CNRS, Toulouse), for 
realizing acoustic wave delay-lines. AFM experiments were carried on the NSI platform.

\section{References}

[1] R. Panphlett, R. McQuilty, K. Zarkos, Neurotoxicology 22 (2001) 401-410.

[2] T. Bahadir, G. Bakan, L. Altas, H. Buykgungar, Enzyme Microbiol. Technol. 41 (2007) 98-102.

[3] Z. Reddad, C. Gérente, Y. Andrès, J.F. Thibault, P. Le Cloirec, Water Res. 37 (2003) 3983-3991.

[4] Y.-Z. Peng, Y.-M. Huang, D.-X. Yuan, L. Yan, Z.-B. Gong, Chin. J. Anal. Chem. 40 (2012) 877-882

[5] K. Jankowski, J. Yao, K. Kasiura, A. Jackowska, A. Sieradzka, Spectrochim. Acta Part B: Atomic Spectrosc. 60 (2005) 369-375.

[6] T.J. Hwang, S.-J. Jiang, J. Anal. Atomic Spectrom. 11 (1996) 353-357.

[7] A.K. Malik, V. Kaur, N. Verma, Talanta 68 (2006) 842-849.

[8] C. Dejous, M. Savart, D. Rebière, J. Pistre, Sens. Actuators 27 (1995) 1.

[9] M. Hepel, M. Hepel, A. Wieckowski, Theory, Experiment and Applications, Marcel Dekker, 1999, pp. 599-630.

[10] L. Sartore, M. Barbaglio, L. Borgese, E. Bontemp, Sens. Actuators B: Chem. 155 (2011) 538-544.

[11] M. Benounis, N. Jaffrezic-Renault, H. Halouani, R. Lamartine, I. DumazetBonnamour, Mater. Sci. Eng. C 26 (2006) 364-368.

[12] P. Doelman, E. Jansen, M. Michels, M. Van Til, Biol. Fertil. Soil 17 (1994) 177184.

[13] J.M. Wood, H.K. Wang, Environ. Sci. Technol. 17 (1983) 582-590.

[14] S. Zhou, C. Wei, C. Liao, H. Wu, J. Environ. Sci. 20 (2008) 1514-1518.

[15] K. Guven, S. Togrul, F. Uyar, S.I. Ozant, D. De Pomerai, Enzyme Microb. Technol. 32 (6) (2003) 658-664.

[16] X. Zhan, J. Li, J. Huang, C. Chen, J. Chin, J. Polym. Sci. 27 (2009) 533-542.

[17] A. Ghadimi, M. Sadrzadeh, T. Mohammadi, J. Membr. Sci. 360 (2010) 509521.

[18] T.C. Merkel, V.I. Bondar, K. Nagai, B.D. Freeman, I. Pinnau, J. Polym. Sci. B: Polym. Phys. 38 (2000) 415-434.

[19] C.I. De Menezes Atayde, Phys, Status Solidi C 7 (2010) 189-192.

[20] N. Li, A. Tourovskaia, A. Folch, Crit. Rev. Biomed. Eng. 31 (2003) 423-488.

[21] B.H. Weigl, R.L. Bardell, C.R. Cabrera, Adv. Drug Deliv. Rev. 55 (2003) 349-377.

[22] I. Gammoudi, H. Tarbague, A. Othmane, Biosens. Bioelectron. 26 (2010) $1723-1726$

[23] C. Zimmermann, D. Rebière, C. Dejous, J. Pistré, E. Chastaing, R. Planade, Sens. Actuator B 76 (2001) 86-94

[24] F. Razan, C. Zimmermann, D. Rebière, C. Dejous, J. Pistré, M. Destarac, B. Pavageau, Sens. Actuators B: Chem. 108 (2005) 917-924

[25] V. Raimbault, D. Rebière, C. Dejous, M. Guirardel, J.L. Lachaud, Sens. Actuators B: Chem. 144 (2010) 318-322.

[26] H. Tarbague, J.-L. Lachaud, S. Destor, L. Vellutini, J.-P. Pillot, B. Bennetau, E. Pascal, D. Moynet, D. Mossalayi, D. Rebière, C. Dejous, J. Integrated Circuits Syst. 2 (2010) 125-133.

[27] V. Raimbault, D. Rebière, C. Dejous, M. Guirardel, V. Conedera, J. Pistré, ECS Trans. 4 (2006) 73-81.

[28] M. Schonhoff, C. Opin, Colloid Interface Sci. 8 (2003) 86-95

[29] J.P. Aimé, Z. Elkaakour, C. Odin, T. Cohen-Bouhacina, D. Michel, J. Curély, A. Dautant, J. Appl. Phys. 76 (1994) 754-762.

[30] S. Gauthier, J.P. Aimé, T. Bouhacina, B. Desbat, A.J. Attias, Langmuir 12 (1996) 4840.

[31] T. Bouhacina, B. Desbat, J.P. Aimé, Tribol. Lett. 9 (2000) 111-117.

[32] A. Simon, T. Cohen-Bouhacina, M.C. Porté, J.P. Aimé, C. Baquey, J. Colloïds Interface Sci. 251 (2002) 278-283.

[33] A. Simon, T. Cohen-Bouhacina, M.C. Porté, J.P. Aimé, J. Amédée, C. Baquey, Cell. Mol. Biol. 50 (2004) 3.

[34] M. Stobiecka, A.A. Molinero, A. Chałupa, M. Hepel, Anal. Chem. 84 (2012) 4970-4978.

[35] A. Simon, T. Cohen-Bouhacina, M.C. Porte, J.P. Aime, J. Amédée, R. Bareille, C. Baquey, Cytom. Part A 5 (2003) 36-47. 